\title{
KESADARAN MASYARAKAT DALAM MEMBAYAR PAJAK BUMI DAN BANGUNAN DI KELURAHAN MAESA UNIMA KECAMATAN TONDANO SELATAN
}

\author{
Oleh: \\ Frelly Manurung, Sjamsi Pasandaran, Jan Rattu \\ Jurusan PPKn FIS Unima \\ Email: spasandaran@unima.ac.id
}

\begin{abstract}
ABSTRAK
Penelitian ini difokuskan pada masalah kesadaran masyarakat dalam membayar Pajak Bumi dan Bangunan. Penelitian ini mengambil lokasi di Kelurahan Maesa Unima, Kecamatan Tondano Selatan. Dengan subjek penelitian ini adalah seluruh anggota masyarakat yang ada dikelurahan maesa unima yang sudah menjadi wajib pajak. Sebagian besar wajib Pajak Bumi dan Bangunan sudah membayar pajak, namun ada juga masyarakat yang belum membayar pajak dan tidak mengerti penggunaan pajak. Pajak merupakan salah satu sumber penerimaan negara, yang sangat penting artinya bagi pelaksanaan dan peningkatan pembangunan nasional menuju kemakmuran dan kesejahteraan masyarakat. Oleh karena itu masyarakat harus berperan aktif, mengerti dan memahami tentang perpajakan. Metode yang digunakan dalam penelitian ini adalah metode penelitian kualitatif dengan pendekatan deskriptif, dengan teknik pengumpulan data melalui wawancara, observasi dan dokumentasi dengan pihak kelurahan beserta beberapa wajib pajak yang ada di Kelurahan Maesa Unima. Hasil penelitian menunjukan bahwa adanya 3 faktor yang mempengaruhi kesadaran masyarakat untuk membayar Pajak Bumi dan Bangunan. Diantara 3 faktor yang sangat mempengaruhi rendahnya kesadaran masyarakat dalam membayar Pajak Bumi dan Bangunan yaitu: 1. Kemampuan Sumber Daya Manusia 2. Kondisi Sosial Ekonomi 3. Kondisi Tempat Tinggal Wajib Pajak
\end{abstract}

Kata Kunci: Kesadaran, Masyarakat, Pajak, Bumi, Bangunan 


\section{PENDAHULUAN}

Negara Indonesia adalah sebuah negara kepulauan yang berciri Nusantara dengan wilayah yang batas-batas dan hak-haknya ditetapkan dengan undangundang. Sebagai negara kesatuan, bangsa Indonesia mempunyai tujuan negara seperti halnya negara-negara lain. Tujuan Negara Kesatuan Republik Indonesia di tuangkan dalam pembukaan UndangUndang Dasar 1945 alinea ke IV yaitu: melindungi segenap bangsa Indonesia dan seluruh tumpah darah Indonesia, memajukan kesejahteraan umum, mencerdaskan kehidupan bangsa dan ikut melaksanakan ketertiban dunia berdasarkan perdamaian abadi dan keadilan sosial (Naskah UUD 1945).

Dalam rangka mewujudkan tujuan negara tersebut, maka pemerintah menempuh langkah dengan jalan melaksanakan pembangunan di semua sektor. Pembangunan nasional yang sedang dilaksanakan pemerintah dewasa ini pada hakekatnya adalah pembangunan manusia seutuhnya dan pembangunan manusia seluruhnya, dengan berdasarkan Pancasila dan Undang-Undang Dasar 1945 guna mencapai tujuan nasional yaitu mewujudkan masyarakat adil dan makmur, material dan spiritual. Dalam rangka mewujudkan tujuan negara tersebut, maka pemerintah menempuh langkah dengan jalan melaksanakan pembangunan di semua sektor seperti sektor pertanian dan sektor industri. Dengan adanya pembangunan di semua bidang pemerintah akan banyak membutuhkan dana untuk pelaksanaanya. Dana yang di peroleh untuk pelaksaan pembangunan berasal dari masyarakat kelurahan maesa unima melalui pajak, pajak memiliki peran yang penting untuk pembangunan nasional, kesejahteraan rakyat melalui tersedianya sarana umum seperti: pendidikan, jalan-jalan, listrik, kesehatan, dan lain-lain. Meningkatkan kehidupan generasi mendatang, kemajuan bangsa. Kemajuan suatu bangsa amat ditentukan melalui kesadaran masyarakat dalam membayar pajak bumi dan bangunan dengan benar. Sebagai warga negara sekaligus merupakan subyek pajak berdasarkan obyek pajak bumi dan bangunan yang dimilikinya mempunyai kewajiban mendaftarkan obyek pajak, menghitung pajak bumi dan bangunan, dan membayar hutang pajaknya menurut ketentuan perundang-undangan pajak bumi dan bangunan yang berlaku.

Data besar pajak APBN dan APBD dalam pembiayaan sektor pembangunan

\begin{tabular}{|l|c|}
\hline \multicolumn{1}{|c|}{ Uraian } & APBN \\
\hline $\begin{array}{l}\text { Pendapatan Negara } \\
\text { - Perpajakan } \\
\text { - Pendapatan Negara } \\
\text { Bukan Pajak }\end{array}$ & $1.750,3$ \\
& $2.498,9$ \\
\hline $\begin{array}{l}\text { Belanja Negara } \\
\text { - Pemerintah Pusat } \\
\text { - Transfer ke Daerah dan } \\
\text { Dana Desa }\end{array}$ & $1.315,5$ \\
\hline
\end{tabular}

- Besar pajak APBN dalam pembiayaan sektor pembangunan $=63,22 \%$

- Besar pajak APBD dalam pembiayaan sektor pembangunan $=36,66 \%$

- Biaya pembangunan dari sektor pajak $=2.080,5$ triliun rupiah

Menurut Andriani dalam Santoso Brotodiharjo, dalam buku Pengantar Ilmu Hukum Pajak (1991:2), pajak adalah iuran kepada negara (yang dapat dipaksakan) yang terhutang oleh yang wajib membayarnya menurut peraturanperaturan, dengan tidak mendapat prestasi kembali, yang langsung dapat ditunjuk, dan yang gunanya adalah untuk membiayai pengeluaran-pengeluaran umum berhubung dengan tugas negara yang menyelenggarakan pemerintahan. Dalam UUD 1945 Pasal 33 ayat 3 menyatakan bahwa bumi dan air dan 
kekayaan alam yang terkandung di dalamnya dikuasai oleh negara dan dipergunakan untuk sebesar-besar kemakmuran rakyat. Oleh karena itu bagi mereka yang memperoleh manfaat dari bumi dan kekayaan alam yang terkandung didalamnya karena mendapat sesuatu hak dari kekuasaan negara, wajib menyerahkan sebagian dari kenikmatan yang di perolehnya itu kepada negara melalui pembayaran pajak.

Sesuai dengan fungsi pajak antara lain: sebagai sumber keuangan negara (Budgetair), juga digunakan sebagai suatu alat yang mengatur atau melaksanakan kebijakan negara dalam lapangan ekonomi (penciptaan lapangan pekerjaan atas berdirinya arsamart), infrastuktur (pembangunan post kamling) dan bidang sosial (pembangunan tempat ibadah).

Sumber penerimaan negara berasal dari sektor pajak dan non pajak. Seiring dengan perkembangan jaman ini, pemerintah lebih menekankan penerimaan negara dari sektor pajak mengingat sektor pajak sangat dominan bagi kepentingan pembangunan infrastruktur, transportasi, pendidikan, kesehatan dan lain-lain.

Upaya pemerintah untuk mendapatkan sektor pajak sebagai salah satu upaya sumber pendapatan negara yang strategis setelah ditetapkan UU No. 6 Tahun 1983 tentang ketentuan umum dan tata cara perpajakan, UU No. 7 Tahun 1984 tentang pajak penghasilan, UU No. 13 Tahun 1985 tentang Bea Materai, UU No. 8 Tahun 1983 tentang Pajak Pertambahan Nilai Atas Barang dan Jasa serta Pajak Penjualan Atas Barang Mewah dan sekaligus UU No. 12 Tahun 1985 tentang pajak bumi dan bangunan. Serta di adakannya penyuluhan-penyuluhan mengenai pajak, akan tetapi penyuluhan tersebut hanya terbatas pada pelaksanaan perpajakan saja, sehingga masalah kesadaran untuk membayar pajak perlu diadakan pengkajian lebih lanjut.

Pada dasarnya faktor yang menghambat pembayar pajak adalah masalah kesadaran masyarakat, dimana perlu diberi pengarahan bahwa pajak itu bukan semata-mata merupakan kewajiban setiap warga negara, tetapi juga merupakan hak setiap masyarakat untuk ikut serta dalam pembiayaan negara melalui pembangunan. Masalah kesadaran masyarakat menjadi faktor yang menghambat pembayaran pajak di kelurahan maesa unima terdapat jumlah penduduk 1. 528 jiwa yang terealisasikan 715 jumlah wajib pajak. 715 jumlah wajib pajak dengan keterangan 357,5 wajib pajak yang membayar dan 357,5 wajib pajak yang tidak membayar pajak. Bedasarkan latar belakang masalah di atas, maka penulis tertarik untuk mengadakan penelitian dengan judul "Kesadaran Masyarakat Dalam Membayar Pajak Bumi Dan Bangunan Di Kelurahan Maesa Unima Kecamatan Tondano Selatan.

\section{KAJIAN TEORI \\ Konsep Kesadaran}

Beberapa pengertian tentang kesadaran dari beberapa ahli:

1. Menurut Kamus Besar Bahasa Indonesia, Kesadaran berasal dari kata sadar yang berarti insaf, merasa tahu atau mengerti. Sedangkan kesadaran adalah keadaaan mengerti akan hal yang dirasakan atau dialami sesorang.

2. AW. Widjaja (1984: 14), mendefinisikan kesadaran berasal dari kata sadar berarti merasa, tahu, ingat kepada keadaan yang sebenarnya, atau ingat akan keadaan dirinya, sedangkan kesadaran diartikan keadaan tahu, mengerti dan merasakan 
(http://lib.unnes.ac.id/7821/1/10266.p df).

Kesadaran merupakan suatu keadaan dimana seseorang melakukan suatu tindakan tanpa adanya paksaan dari pihak manapun. Menurut Feira (2002:125) "Kesadaran merupakan kemauan disertai dengan tindakan dari refleksi terhadap kenyataan." (https://edhyriyono.wordpress.com/tugastugas/proposal-skripsi/). Jadi kesadaran ialah suatu keadaan dimana setiap orang yang memiliki kesadaran melakukan suatu tindakan atas kemauannya sendiri tanpa ada paksaan dari orang lain.

Jadi kesadaran adalah suatu keadaan, dimana setiap orang yang memiliki kesadaran, ia akan merasa, tahu, mengerti, dan melakukan tindakan tanpa adanya paksaan dari pihak manapun.

\section{Kesadaran Membayar Pajak}

Kesadaran membayar pajak datang dari dalam pribadi wajib pajak, bahwa tanpa diingatkan, ada atau tidak adanya sanksi wajib pajak tetap memenuhi kewajibannya untuk membayar pajak. Sehingga kesadaran masyarakat dipengaruhi oleh adanya kesadaran hukum yang timbul dalam diri masyarakat karena adanya pengetahuan tentang hukum, pemahaman hukum serta sanksi jika melanggarnya (http://lib.unnes.ac.id/7821/1/10266.pdf)

Jadi kesadaran membayar pajak ialah suatu keadaan dimana wajib pajak membayar pajak tanpa adanya paksaan dari orang lain.

\section{Kesadaran Hukum}

Hukum adalah himpunan petunjukpetunjuk (perintah-perintah dan laranganlarangan) yang mengatur tata tertib dalam suatu masyarakat, dan oleh karena itu seharusnya ditaati oleh anggota masyarakat yang bersangkutan.
Beberapa pengertian tentang kesadaran hukum dari beberapa ahli:

1. Kesadaran hukum adalah determinan materil dari pada timbul dan berprosesnya hukum didalam masyarakat oleh karena hukum yang berlaku dalam masyarakat harus sesuai dan didasarkan pada kesadaran hukum masyarakatnya

(Abdurrahman, 1980:13)

2. Menurut Kamus Bahasa Indonesia, Kesadaran hukum adalah kesadaran seseorang akan nilai-nilai yang terdapat dalam diri manusia mengenai hukum yang ada atau kesadaran seseorang akan pengetahuan bahwa suatu perilaku tertentu diatur oleh hukum.

3. Kesadaran hukum adalah hukum harus ditaati manusia karena hukum bersumber dan sesuai dengan kesadaran hukum manusia (Achmad Roestandi, 2012:12).

Kesadaran hukum merupakan sebagai suatu keseluruhan yang mencakup pengetahuan tentang hukum, penghayatan fungsi hukum dan ketaatan kepada hukum.

\section{Pengertian Pajak}

Pajak menurut Undang-Undang No. 28 Tahun 2007 tentang Ketentuan Umum dan Tata Cara Perpajakan : Pajak adalah suatu kewajiban kenegaraan dan pengabdian serta peran aktif warga negara dan anggota masyarakat lainnya untuk membiayai berbagai keperluan negara berupa Pembangunan Nasional yang pelaksanaannya diatur dalam Undang-Undang dan peraturan-peraturan untuk tujuan kesejahteraan bangsa dan negara (Rimsky K. Judisseno,2005:7).

Pajak adalah iuran rakyat kepada kas negara berdasarkan undang-undang (yang dapat dipaksakan) dengan tidak mendapat jasa timbal, yang langsung 
dapat ditunjukkan dan yang digunakan untuk membayar pengeluaran umum (Rochmat Soemitro, 1974:8).

Pajak adalah iuran masyarakat kepada negara (yang dapat dipaksakan) yang terutang, membayarnya menurut peraturan-peraturan, dengan tidak mendapat prestasi kembali, yang langsung dapat ditunjuk, dan yang gunanya adalah untuk membiayai pengeluaran-pengeluaran umum berhubung tugas negara untuk menyelenggarakan pemerintahan (Adriani dalam Santoso Brotodihardjo, 1991:2).

Menurut Ray M. Sommerfeld, dan H. R. Brock, Pajak adalah suatu pengalihan sumber dari sektor swasta ke sektor pemerintah, bukan akibat pelanggaran hukum, namun wajib dilaksanakan, berdasarkan ketentuan yang ditetapkan lebih dahulu, tanpa mendapat imbalan yang langsung dan seimbang, agar pemerintah dapat melaksanakan tugas-tugasnya untuk menjalankan pemerintahan (https://id.wikipedia.org/wiki/Pajak).

Deutsche Ordnung, Pajak adalah bantuan uang secara kebetulan atau secara berjangka (dengan tidak ada kontraprestasinya), yang dipungut oleh badan yang bersifat umum (=negara), untuk memperoleh pendapatan, dimana terjadi suatu Tatbestand (=sasaran pemajakan), yang karena undang-undang telah menimbulkan hutang pajak (id.wikipedia.org/wiki/pajak).

Dari definisi-definisi diatas dapat ditarik kesimpulan bahwa pajak dipungut oleh negara berdasarkan Undang-Undang serta peraturan pelaksanaanya. Dalam membayar pajak, tidak dapat ditunjukkan adanya kontra prestasi individual oleh pemerintah. Pajak diperuntukan bagi pengeluaran pemerintah sebagai sumber keuangan negara.

\section{Fungsi Pajak}

1. Fungsi Budgetair/Finansial

Fungsi Budgetair disebut fungsi utama pajak, atau fungsi fiscal yaitu suatu fungsi dalam mana pajak dipergunakan sebagai alat untuk memasukkan dana secara optimal ke kas negara berdasarkan undang-undang perpajakan yang berlaku. Fungsi ini disebut fungsi utama karena fungsi inilah yang secara historis pertama kali timbul. Berdasarkan fungsi ini, pemerintah yang membutuhkan dana untuk membiayai berbagai kepentingan memungut pajak dari penduduknya.

Yang dimaksud dengan memasukkan dana secara optimal ke kas negara berdasarkan undang-undang perpajakan yang berlaku adalah:

1. Jangan sampai ada Wajib Pajak/Subjek Pajak yang tidak memenuhi sepenuhnya kewajiban perpajakannya.

2. Jangan sampai ada Objek Pajak yang tidak dilaporkan oleh wajib Pajak kepada fiskus.

3. Jangan sampai ada Objek Pajak yang terlepas dari pengamatan atau penghitungan fiskus.

4. Fungsi Regulerend/Mengatur

Fungsi regulerend atau fungsi mengatur disebut juga fungsi tambahan, yaitu suatu fungsi dalam mana pajak dipergunakan oleh pemerintah sebagai alat untuk mencapai tujuan tertentu. Disebut sebagai fungsi tambahan karena fungsi ini hanya sebagai pelengkap dari fungsi utama pajak, yakni fungsi budgetair. Untuk mencapai tujuan tersebut maka pajak dipakai sebagai alat kebijaksanaan, misalnya: Pemerintah menentukan tujuan untuk memberantas/menghilangkan kebiasaan mabuk-mabukan dikalangan generasi muda. Disini pemerintah dapat menggunakan pajak sebagai alat untuk mencapai tujuan tersebut dengan cara 
memajaki harga minuman keras sedemikian rupa, sehingga tidak terjangkau lagi oleh sebagian besar generasi muda.

\section{Manfaat pajak}

\section{Manfaat Pajak Bagi Negara}

Pajak sangat bermanfaat bagi negara. Secara lengkap pajak banyak digunakan untuk: (1) Membiayai pengeluaran-pengeluaran negara, seperti: pengeluaran yang bersifat self liquiditing, contohnya: pengeluaran untuk proyek produktif barang ekspor. (2) Membiayai pengeluaran reproduktif, seperti: pengeluaran yang memberikan keuntungan ekonomis bagi masyarakat, contohnya: pengeluaran untuk pengairan dan pertanian. (3) Membiayai pengeluaran yang bersifat tidak self liquiditing dan tidak reproduktif, contohnya: pengeluaran untuk pendirian monumen dan objek rekreasi. (4) Membiayai pengeluaran yang tidak produktif, contohnya: pengeluaran untuk membiayai pertahanan negara atau perang dan pengeluaran untuk penghematan di masa yang akan datang yaitu pengeluaran untuk anak yatim piatu.

2. Manfaat Pajak Bagi Masyarakat

a. Fasilitas umum dan infrastruktur, seperti: jalan, jembatan, sekolah, rumah sakit

b. Pertahanan dan keamanan, seperti: bangunan, senjata, perumahan hingga gaji-gajinya

c. Subsidi pangan dan Bahan Bakar Minyak

d. Kelestarian Lingkungan hidup dan Budaya

e. Dana Pemilu

f. Pengembangan Alat transportasi Massa, dan lain-lainnya.

Pajak yang telah disetorkan masyarakat akan digunakan negara untuk kesejahteraan masyarakat, antara lain: memberi subsidi barang-barang yang dibutuhkan masyarakat dan membayar utang-utang negara. Selain itu pajak juga digunakan untuk menunjang Usaha Mikro, Kecil, dan Menengah agar perekonomian dapat terus berkembang (https://www.cermati.com/artikel/manfaat -pajak-bagi-masyarakat-dan-negara).

Pengertian Pajak Bumi dan Bangunan

Pajak bumi dan bangunan adalah pajak yang dipungut atas tanah dan bangunan karena adanya keuntungan dan/atau kedudukan sosial ekonomi yang lebih baik bagi orang atau badan yang mempunyai suatu hak atasnya atau memperoleh manfaat dari padanya. (https://id.wikipedia.org/wiki/Pajak_bumi _dan_bangunan).

Pajak Bumi dan Bangunan adalah pajak negara yang dikenakan atas objek pajak bumi dan bangunan yang diatur pengenaannya berdasarkan UndangUndang Nomor 12 Tahun 1985 tentang Pajak Bumi dan Bangunan sebagaimana telah diubah dengan undang-undang nomor 12 Tahun 1994.

1. Subjek Pajak Bumi dan Bangunan Subyek PBB menurut Pasal 1 ayat (1) UU No. 12 Tahun 1985 sebagaimana telah diubah dengan UU No. 12 Tahun 1994 adalah orang atau badan yang secara nyata:

a. mempunyai suatu hak atas bumi.

b. memperoleh manfaat oleh bumi.

c. memiliki, menguasai, dan memperoleh manfaat atas bangunan.

Subjek pajak adalah orang atau badan hukum yang dikenakan kewajiban membayar pajak.

\section{Objek Pajak Bumi dan Bangunan}

Objek pajak bumi dan bangunan adalah "bumi dan/atau bangunan" 
1. Bumi adalah permukaan bumi (tanah dan perairan) dan tubuh bumi yang ada dibawahnya. Contoh: sawah, ladang, kebun, tanah, pekarangan, tambang, dll.

2. Bangunan adalah konstruksi teknik yang ditanam atau dilekatkan secara tetap pada tanah dan/atau perairan diwilayah Republik Indonesia. Contoh: rumah tempat tinggal, bangunan tempat usaha, gedung bertingkat, pusat perbelanjaan, jalan tol, kolam renang, anjungan minyak lepas pantai, dll.

\section{Sistem Pemungutan Pajak}

\section{Official assessment system}

Official assessment system, yakni suatu sistem pemungutan pajak yang memberi wewenang kepada pemerintah (fiscus) untuk menentukan besarnya pajak yang terutang oleh wajib pajak. Ciri-cirinya:
a. Wewenang untuk menentukan besarnya pajak terutang ada pada fiscus;

b. Wajib pajak bersifat pasif:

c. Utang pajak timbul setelah dikeluarkannya Surat Ketetapan Pajak oleh fiscus.

\section{Self assessment system}

Self assessment system, yakni suatu sistem pemungutan pajak yang memberi wewenang kepada wajib pajak untuk menentukan sendiri besarnya pajak yang terutang. Ciri-cirinya:

a. Wewenang untuk menentukan besarnya pajak terutang ada pada wajib pajak sendiri;

b. Wajib pajak aktif, mulai dari menghitung, menyetor dan melaporkan sendiri pajak yang terutang.

c. Fiscus tidak ikut campur dan hanya menngawasi.

3. With Holding sistem.

With Holding sistem, yakni sistem pemungutan pajak yang memberi wewenang kepada pihak ketiga (bukan fiscus dan bukan wajib pajak yang bersangkutan) untuk menentukan besarnya pajak yang terutang oleh wajib pajak. Ciri-cirinya: Wewenang menentukan besarnya pajak yang terutang ada pada pihak ketiga selain fiscus dan wajib pajak.

\section{METODOLOGI PENELITIAN}

Metode penelitian sebagai cara yang dipakai untuk menyelidiki masalah guna mencapai tujuan menggunakan metode pendekatan kualitatif. Jenis penelitian yang dilakukan adalah kualitatif karena meneliti data-data dari kantor kelurahan untuk dijadikan sebagai sumber penelitian yang berupa catatan dan dokumen. Menurut Sugiyono (2005:1), yang dimaksud dengan penelitian kualitatif merupakan jenis penelitian yang digunakan untuk meneliti pada kondisi objek alamiah, dan hasil penelitian kualitatif lebih menekankan makna.

Sumber data primer, diperoleh dari hasil penelitian dilapangan secara langsung dengan pihak-pihak yang mengetahui persis masalah yang akan dibahas, seperti wawancara dan memberikan kuasioner. Wawancara adalah cara pengumpulan data dengan mengadakan tanya jawab langsung kepada objek yang telah diteliti. Dalam hal ini informan adalah wajib pajak, petugas kelurahan yang menangani PBB. Informan adalah orang-orang yang terlibat dalam penelitian ini yang jumlah wajib pajak 715 dan petugas kelurahan yang menangani PBB berjumlah 2 orang. Karena informasinya dibutuhkan dalam melakukan penelitian. Sumber data sekunder, untuk memperoleh sumber data sekunder penulis menggunakan teknik dokumentasi. Dokumentasi yang digunakan dalam penelitian ini adalah dokumen-dokumen dan arsip yang ada di 
Kantor Kelurahan Maesa Unima. Dokumentasi yang didapat dalam penelitian ini adalah berupa catatancatatan mengenai jumlah penduduk, gambaran umum kelurahan maesa unima, dan data perolehan penerimaan Pajak Bumi dan Bangunan Kelurahan Maesa Unima untuk melengkapi data primer yaitu yang berhubungan dengan perpajakan.

Adapun teknik analisis data yang digunakan yakni dengan menelaah, dan mereduksi data yang bersikap deskriptif yang diperoleh di lapangan, kemudian di kategorisasikan untuk di periksa selanjutnya di tafsirkan. Bogdan dan Taylor (1957:32) analisis data adalah sebagai proses mencari usaha secara formal untuk menemukan tema dengan merumuskan ide seperti yang di sarankan oleh data dan sebagai usaha untuk memberikan bantuan pada tema dan ide itu.

\section{HASIL PENELITIAN}

Berdasarkan hasil penelitian yang ditemukan melalui wawancara yang dilakukan kepada wajib pajak di Kelurahan Maesa Unima, selanjutnya pada bagian ini peneliti dapat menguraikannya sesuai dengan indikator yang diteliti yakni :

1) Pemahaman tentang Pajak Bumi dan Bangunan

2) Mengerti arti dari Pajak Bumi dan Bangunan

3) Senang dalam membayar Pajak Bumi dan Bangunan

Kegiatan memahami sesuatu adalah pemahaman sangat penting bagi seluruh orang, tidak dapat ditawar-tawar lagi. Hal ini didasarkan pada suatu pemikiran sebagian besar pemerolehan ilmu yang dilakukan oleh banyak orang melalui aktivitas pemahaman.
Pemahaman berasal dari kata paham yang mempunyai arti mengerti benar, sedangkan pemahaman merupakan proses perbuatan cara memahami (Em Zul, Fajri \& Ratu Aprilia Senja, 2008 : 607-608).

Berdasarkan hasil penelitian yang telah dilakukan, peneliti menemukan bahwa wajib pajak yang ada dikelurahan Maesa Unima tidak cukup baik kesadarannya sebagai wajib pajak dan sebagai warga negara yang baik dalam membayar pajak bumi dan bangunan.

Di sini peneliti menemukan beberapa kendala yang menyebabkan rendahnya kesadaran dan pemahaman wajib pajak dalam membayar pajak bumi dan bangunan adalah sebagai berikut :

1) Kemampuan Sumber Daya Manusia

Sumber daya manusia merupakan potensi yang terkandung dalam diri manusia untuk mewujudkan perannya sebagai makhluk sosial yang adaptif dan transformatif yang mampu mengelola dirinya sendiri serta seluruh potensi yang terkandung dalam menuju tercapainya kesejahteraan kehidupan dalam tatanan yang seimbang dan berkelanjutan.

2) Kondisi Sosial Ekonomi

Keadaan sosial masyarakat menentukan juga agar tercapainya realisasi Pajak Bumi dan Bangunan setiap tahun. Kesadaran masyarakat terhadap pembayaran pajak perlu mendapatkan perhatian, terutama terhadap masyarakat yang berpenghasilan rendah. Faktor sosial seperti perekonomian dan pemahaman tentang pajak.

3) Kondisi Tempat Tinggal Wajib Pajak

Faktor domisili atau tempat tinggal wajib pajak merupakan salah satu dari sekian banyak hembatan dalam pemungutan Pajak Bumi dan Bangunan, hal ini sangat merugikan akibatnya dalam pemungutan dalam target tidak tercapai. tempat tinggal wajib pajak berada diluar 
kelurahan merupakan faktor penghambat kolektor dalam memungut Pajak Bumi dan Bangunan.

4) Kepemimpinan

Pemimpin merupakan faktor penting dalam sebuah organisasi. Begitu pula Kepala kelurahan. Kepala Kelurahan sebagai pemimpin di kelurahan harus menjalankan tugas pokok dan fungsinya sesuai dengan peraturan yang berlaku. Kepala Kelurahan diberikan tanggung jawab dalam perencanaan dan pemungutan Pajak Bumi dan Bangunan dan dilaksanakan oleh Ketua Rukun Tetangga (RT).

Mengerti arti dari Pajak Bumi dan Bangunan. Mengerti adalah menangkap suatu ilmu. Sebagai warga negara yang baik mengerti bahwa Indonesia adalah negara hukum. Wajib pajak harus mengerti akan arti dari pengertian dan hukum yang mengatur tentang Pajak Bumi dan Bangunan.

Dari hasil penelitian yang telah dilakukan, peneliti melihat cukup baik wajib pajak yang ada dikelurahan Maesa Unima mengerti pengertian dari pajak bumi dan bangunan. Senang dalam membayar Pajak Bumi dan Bangunan. Senang adalah puas, tanpa rasa susah dan kecewa.

Dari hasil penelitian yang telah dilakukan, peneliti melihat sebagian besar masyarakat atau wajib pajak yang ada di Kelurahan Maesa Unima senang dalam membayar Pajak Bumi dan Bangunan. Namun kesadaran dari wajib pajaknya masih minim, dikarenakan faktor finansial dan kondisi tempat tinggal.

\section{KESIMPULAN DAN SARAN Kesimpulan}

Berdasarkan hasil penelitian dan pembahasan pada bab sebelumnya, maka dapat disimpulkan sebagai berikut:
1. Kurangnya pemahaman masyarakat tentang pajak bumi dan bangunan ini disebabkan karena tidak adanya sosialisasi kepada wajib pajak tentang pajak.

2. Suasana wajib pajak (belum memiliki uang) sangat mempengaruhi kesadaran untuk membayar pajak bumi dan bangunan. Wajib pajak sadar untuk membayar pajak bumi dan bangunan namun mereka terhalang oleh tidak memiliki uang lebih untuk membayar pajak bumi dan bangunan.

3. Wajib pajak yang tidak berdomisili di kelurahan maesa unima.

4. Kurangnya informasi tentang aturanaturan perpajakan, hal ini disebabkan karena tidak adanya sosialisasi dari pemerintah dan dinas perpajakan, sehingga masih ada wajib pajak yang tidak membayar pajak.

5. Tidak adanya sanksi yang tegas diberikan kepada penunggak pajak

\section{Saran}

1. Untuk Pemerintah kelurahan perlu mengadakan sosialisasi tentang Pajak agar menambah wawasan dan meningkatnya kesadaran wajib pajak untuk membayar Pajak Bumi dan Bangunan

2. Sebagai warga negara yang baik, seharusnya memberikan partisipasi untuk ikut membangun negara dengan membayar pajak tepat waktu, untuk kepentingan dan kesejahteraan negara dan masyarakat serta memberikan masukan baik kritikan maupun solusi kepada pemerintah berkaitan dengan Pajak Bumi dan Bangunan.

3. Pemerintah lebih tegas dalam bertindak dalam memberikan sanksi bagi wajib pajak sesuai dengan peraturan perundang-undangan yang berlaku. 


\section{DAFTAR PUSTAKA}

Y. Sri Pudyatmoko, 2004, Pengantar Hukum Pajak, Penerbit ANDI.

Nurmantu, Safri, Pengantar Perpajakan; edisi 2. Jakarta: Granit 2003.

Rismky K. Judisseno, Pajak dan Strategi Bisnis, Penerbit PT Gramedia Pustaka Utama. Jakarta, 2005.

Dirjen Perpajakan. 2001. Brosur Pajak Bumi dan Bangunan dan Pajak Penghasilan.

Achmad Roestandi. 2012. Etika dan Kesadaran Hukum Internalisasi Hukum dan Ekternalisasi Etika. Tangerang: Jelajah Nusa.

Abdurrahman. 1980. Aneka Masalah Dalam Praktek Penegakan Hukum di Indonesia. Bandung: Penerbit Alumni.

I Gusti Ngurah Rai. 2014. Pengantar Hukum Indonesia.

Harbani Pasalong. 2013. Metode Penelitian Administrasi Publik. Bandung: Alfabeta.

Riduwan. 2015. Metode dan Teknik Menyusun Proposal Penelitian. Bandung: Alfabeta.

Sugiyono. 2017. Metode Penelitian Kuantitatif, Kualitatif dan R\&D. Bandung: Alfabeta.

Departemen Pendidikan Nasional. 2005. Kamus Bahasa Indonesia. Jakarta: Balai Pustaka.

Undang-Undang Dasar 1945 Negara Republik Indonesia.

UU No. 6 tahun 1983 tentang ketentuan umum dan tata cara perpajakan.

UU No. 7 tahun 1984 tentang pajak penghasilan.

UU No. 8 tahun 1983 tentang PPn dan penjualan atas barang mewah.

UU No. 12 tahun 1985 tentang pajak bumi dan bangunan.

UU No.13 tahun 1985 tentang bea materai

edhyriyono.wordpress.com/tugas.../proposal-skrip

id.wikipedia.org/wiki/pajak

http://akmapala09.blogspot.co.id/2011/10/

pengertian-pemahaman-menurut-para-ahli.html

cermati.com/artikel/manfaat-pajak-bagi-masyarakat-dan-negara

http://digilib.unila.ac.id/11103/13/II.pdf 